\title{
ELECTION MANAGEMENT IN CAMEROON Progress, Problems And Prospects
}

\author{
Thaddeus Menang
}

\author{
Thaddeus Menang is Advisor at the National Elections Observatory \\ P O Box 13506, Yaoundé, Cameroon \\ Tel.: + 2377715571 \\ e-mail: tmenang@yahoo.com
}

\begin{abstract}
Judged by internationally accepted norms and standards election management in Cameroon stands out as peculiar in more than one respect. Firstly, election management tasks are performed by a multiplicity of bodies and institutions, making it difficult to determine who is really responsible at each stage of the process. Secondly, the conduct of elections is governed by a battery of cross-referencing laws which election stakeholders often find hard to interpret and apply.

The problems arising from this situation need to be and are, presently, being addressed within the framework of reforms that target, on the one hand, the adoption of a single, updated and enforceable electoral law and, on the other, the setting up of a viable election management body and the introduction of modern management methods.
\end{abstract}

\section{INTRODUCTION}

Whereas in the older and better-established democracies of the world election management has become a routine that, more often than not, produces satisfactory results, most of the budding democracies of the Third World are still grappling with the problem of determining which election management procedures are best suited to their specific national contexts. The older democracies themselves tend to differ one from the other, not only in terms of the electoral systems they have put in place but also as regards the specific election management procedures they have adopted. These variations raise the question of whether the management of elections in a democratic context can be said to be governed by a set of internationally accepted norms and standards. 
Despite the differences observed here and there in the practice of conducting elections over the years from one country to the next, the convergence of various democratic traditions can be said to have given rise to what may be considered the norms and standards of election management.

This paper examines critically the management of elections in Cameroon against the backdrop of such norms and standards. It starts off with a discussion of recent efforts among some African states to determine common guiding principles for the conduct of free, fair and credible elections on the continent. It then goes on to outline election management practices in Cameroon and the problems they pose. It ends with a peek at the future of election management in Cameroon and in those countries which, like it, are still struggling to lay a solid institutional foundation for the consolidation of democracy.

\section{NORMS AND STANDARDS FOR ELECTION MANAGEMENT}

In the more advanced democracies of the world norms and standards for elections have become an integral part of the democratic practice and culture, to the extent that they hardly need to be codified. This is unlike the situation in most African and Third World countries where democratic cultures are either non-existent, newly emergent or under restoration and where the people have constantly to remind themselves what democracy is. Such efforts to remain on track have led African countries to adopt various principles and guidelines for election management. Some of these are reviewed below.

\section{PRINCIPLES AND GUIDELINES FOR AFRICAN STATES}

African leaders, intellectuals, civil society leaders and election managers meeting at both continental and (sub-) regional fora have, in recent years, reflected on the conduct of elections on the continent and issued guiding principles that should eventually form the basis for election management norms and standards.

One such encounter was at the 38th Ordinary Session of the Organisation of African Unity (OAU) held in Durban, South Africa, on 28 July 2002. In their Declaration on the Principles Governing Democratic Elections in Africa ${ }^{1}$ African leaders accepted that democratic elections should be conducted:

a) freely and fairly;

b) under democratic constitutions and in compliance with supportive legal instruments;

This declaration was adopted by the African Union, which came into being at the end of the Durban Summit. 
c) under a system of separation of powers that ensures, in particular, the independence of the judiciary;

d) at regular intervals, as provided for in national constitutions;

e) by impartial, all-inclusive, competent, accountable electoral commissions staffed by well-trained personnel and equipped with adequate logistics.

Meeting two years later in Mauritius, Southern African leaders, heads of state, and governments of the member states of the Southern African Development Community (SADC) committed themselves to a regional version of the AU Declaration by adopting the Principles and Guidelines Governing Democratic Elections. These were as follows:

- The establishment of appropriate institutions to address thorny issues relating to election management, such as codes of conduct, citizenship, residency, age requirements and other voter/candidate eligibility conditions.

- The establishment of impartial, all-inclusive, competent and accountable national election management bodies staffed by qualified personnel.

- The establishment of relevant courts to arbitrate electoral disputes.

- The prevention and repression of electoral fraud.

- The provision of adequate funding for elections.

- The transparency and integrity of the entire electoral process.

- The enhancement of the participation in elections of women, the disabled, and youth.

Through the guiding principles outlined above African leaders are seen to have addressed most of the core concerns regarding election management. What remains to be seen is how well individual African states will be able to adopt and abide by these norms and standards. In particular, the challenge will revolve around how African states review their legal frameworks to conform with these norms and standards.

\section{ELECTION MANAGEMENT BODIES}

Given the centrality of the election management bodies (EMBs) to the electoral process in many African states today the discussions of norms and standards for election management tend to focus considerable attention on these institutions: their status, membership, tenure, mode of funding, and so on. Here again there 
can be said to be more or less clearly defined principles although in practice the situation tends to differ from one context to the next. The main principles and current practical trends among African countries are outlined below.

To be efficient and credible EMBs should possess the following, generally accepted, characteristics:

a) They should be independent, that is, they must not be part of the formal government bureaucracy.

b) Their members should be selected on the basis of '.. the individuals' calibre, stature, public respect, competence, impartiality and their knowledge of elections and political development processes' (SADC Parliamentary Forum 2001).

c) Their members should be appointed after consultation with election stakeholders and the approval of parliament.

d) Members' mandates must be durable and secure, preferably entrenched in the constitution.

e) Membership of EMBs should be inclusive, that is, representative of both sexes and of all social and age groups.

f) EMBs must be run by staff recruited and dismissed only on the basis of lack of professionalism and competence.

g) EMBs should be efficient, neutral, objective, transparent and accountable to parliament rather than to government.

h) EMBs should have autonomous budgets that are voted directly by parliament.

A study of EMBs on the African continent shows that although their functions tend to remain more or less the same, they differ in size, composition and status from one country to the next.

Basing his analysis on institutional location, that is, on the extent of their political autonomy vis-à-vis the government, Mozaffar (2002) identifies three broad types of EMBs:

- Non-autonomous EMBs that are located within the formal government bureaucracy.

- Semi-autonomous EMBs that are located within the formal government bureaucracy but are placed under the supervision of an autonomous body established specifically for that purpose.

- Autonomous EMBs that are otherwise known as 'independent electoral commissions' because they are located outside the formal government bureaucracy. 
This classification is useful as a starting point but it needs to be reviewed for various reasons. Firstly, it makes no reference to membership in terms of composition and security of tenure of members. It also does not make it clear which of the two bodies in the second category is semi-autonomous - the one located within the formal sphere of government or the supervisory body - or even whether or not both bodies are to be seen as parts of one and the same 'semi-autonomous' EMB.

\section{ELECTION MANAGEMENT IN CAMEROON}

Cameroon achieved its independence from France and Great Britain more than 40 years ago. ${ }^{2}$ Since then it has organised numerous elections at both national and local level. The outcome of each of these elections has elicited various reactions both at home and abroad. What is, however, clear to the people of Cameroon and to most observers is that election management in the country needs to be improved. This section of the paper provides a brief background to Cameroon's democratic process. It also outlines the instruments governing elections in the country and outlines the institutional framework for election management.

\section{Background to Cameroon's democratic process}

When Cameroon acceded to independence in the early 1960s the country had a form of multiparty democracy that allowed for the existence of political parties which took part in elections to choose members of state assemblies and of a federal parliament through universal suffrage. But this situation did not last for long.

Within six years of independence and of the unification of the English- and French-speaking sections of the country the then President, Ahmadou Ahidjo, who was at the helm of the Union Camerounaise, invited leaders of the other authorised political parties to join him in forming a single 'unified' party for the purposes of nation building. The leaders of the other political parties entered into an agreement with him and the Cameroon National Union (CNU) was formed. The CNU existed as a single party until 1985 when it was replaced during the Bamenda CNU congress by the Cameroon People's Democratic Movement (CPDM), with the new President, Mr Paul Biya, a former prime minister who had taken office after President Ahmadou Ahidjo's resignation in November 1982, at the helm.

2 French Cameroons acceded to independence in 1960. Later, after a plebiscite held in 1961, the Englishspeaking Southern Cameroons opted to join French Cameroons, forming the Federal Republic of Cameroon on 1 October 1961. The federal state became a unitary state in 1972, after a referendum. 
The CPDM remained Cameroon's only political party until December 1990 when a law was passed by the National Assembly and enacted by President Biya authorising the return to multiparty politics. From 1991 onwards numerous political parties were formed and authorised. The proliferation of parties since then - nearly 200 have been authorised - makes it difficult to determine the numbers currently in existence.

The first multiparty elections following this return to political pluralism took place in 1992 when legislative elections were held in March and a presidential poll in October. While the outcome of the legislative elections was relatively calm, the boycott of these elections by some of the principal political parties gave rise during the presidential election to results which were violently contested by leaders and members of the Social Democratic Front (SDF), which had won almost as many votes as the ruling CPDM party, whose candidate was declared by the Supreme Court to have won the election. The SDF accused officials of the Ministry of Territorial Administration (Ministry of the Interior), who were largely responsible for the conduct of the poll, of complicity with the ruling party.

Subsequent elections, in 1996 and 1997, also gave rise to protests from most opposition parties, some of which, once again, decided to boycott the presidential election held in 1997. These parties continued to press for political reform, particularly the setting up of an Independent Electoral Commission (IEC), until 2000 when, on 19 December, a law was enacted to set up a National Elections Observatory (NEO), whose duty it would henceforth be to supervise and control all elections and referendums organised in the country.

Although this new measure did not entirely satisfy those who had been pressing for the setting up of an Independent Electoral Commission it reduced considerably the political tension that had threatened to disrupt national harmony and offered an opportunity for the relatively peaceful organisation of council and legislative elections in June 2002 and of a presidential election in October 2004. After those elections most national and international observers agreed that there had been a marked improvement in the conduct of elections but they argue that there is need for further improvement. They point to two key areas where such improvement is needed: election legislation (the electoral code) and the registration of voters.

\section{Instruments governing elections in Cameroon}

Before discussing who does what in the management of elections in Cameroon, it is worthwhile outlining the legal framework of the conduct of elections in the country. This framework includes: 
- laws and regulations governing the organisation of elections;

- laws and regulations governing the supervision of elections;

- laws and regulations governing political parties and the financing of political parties and election campaigns.

Laws and regulations governing the organisation of elections

Three different laws govern the organisation of elections:

- Law No 92-002 of 14 August 1992, which lays down conditions for the election of municipal councillors;

- Law No 91-020 of 16 December 1991 (Modified by Law No 97-13 of 19 March 1997), which lays down conditions governing the election of members of Parliament;

- Law No 92-10 of 17 September 1992 (Modified by Law No 97-020 of 9 September 1997), which lays down conditions governing election to the presidency of the Republic.

In order to clarify and further specify certain provisions of the laws listed above, the president of the Republic signs decrees, like the one that maps out electoral constituencies and determines the number of parliamentary seats in each of these constituencies. The Minister of Territorial Administration and Decentralisation (MINATD), who is responsible for the practical organisation of elections, also issues ministerial orders and circular letters whenever necessary.

Laws and regulations governing the supervision of elections

Law No 2000/016 of 19 December 2000 (modified by Law No 2003/015 of 22 December 2003) sets up a National Elections Observatory, which is responsible for supervising elections to ensure that all the provisions of the electoral laws are respected.

This law is further explained in two presidential decrees, Nos 2001/306 of 8 October 2001 and 2001/397 of 20 December 2001. These decrees relate to the various structures of the observatory and spell out instructions for how these structures should be run.

Laws and regulations governing political parties and the financing of parties and election campaigns

- Law No 90/056 of 19 December 1990 governs conditions for setting up political parties.

- Law No 2000/15 of 19 December 2000 institutes public financing of political parties and of election campaigns. Decree No 2001/305 of 
8 October 2001 sets up a commission to monitor the use of public funds by political parties.

These, in a nutshell, are the legal instruments that govern elections in Cameroon. Many critics argue that there are too many overlapping and confusing provisions in these laws and that this gives rise to disagreement over their interpretation and implementation. There have been calls for these laws to be updated and assembled into one comprehensive electoral code.

\section{ELECTION MANAGEMENT BODIES: PROGRESS?}

Election management in Cameroon is not entrusted to a single body although at every stage in the electoral process the shadow of the Ministry of Territorial Administration and Decentralisation (MINATD) looms large over the various other bodies entrusted by the law with specific tasks. The bodies involved in the management of elections in Cameroon fall into four broad categories: joint commissions, the MINATD, the courts and the NEO.

\section{Joint commissions}

The law provides for the setting up of joint commissions, which usually comprise representatives of the administration, of political parties and sometimes of civil society who are responsible for various election management tasks as follows:

- Joint commissions responsible for the registration of voters and for revising and updating voters' rolls.

- Joint commissions responsible for overseeing the establishment and distribution of voters' cards.

- Supervisory commissions responsible for supervising the work of the two commissions cited above and rectifying errors committed at the lower level. Supervisory commissions are also responsible for assembling legislative and presidential election results and forwarding them from the polling stations to a higher, national votecounting commission and for publishing the final results of council elections.

- Local polling commissions responsible for conducting the poll and the vote count.

- A national commission is set up during legislative and presidential elections to compile the final results and forward them to the Constitutional Council for approval and publication. 


\section{The Ministry of Territorial Administration and Decentralisation}

Working alongside the various commissions, MINATD, through officials placed all along the line, takes key election management decisions as follows:

- The Senior Divisional Officer (SDO) signs prefectoral orders to set up various joint commissions responsible for voter registration and the overseeing of the handling of voters' cards as well as the supervisory commissions.

- The Divisional Officer (DO) draws up the final roll of voters in the administrative unit under his responsibility.

- The DO organises the establishment and distribution of voters' cards under the control of a special commission set up to that effect.

- The SDO examines applications from prospective candidates for council and parliamentary elections and accepts or rejects them in accordance with the law.

- The MINATD examines applications from prospective candidates for the presidential elections and accepts or rejects them in accordance with the law: MINATD also publishes the final lists of candidates authorised to run for each election.

- The MINATD issues orders setting up polling stations in all constituencies and fixes the voting procedures to be followed on polling day.

- The DO signs decisions to set up local polling commissions.

- The MINATD signs an order to set up the National Vote Counting Commission.

\section{The courts}

The courts and members of the judiciary also take part in election management either as chairpersons of the supervisory commissions and the National Vote Counting commission listed above or as arbitrators of electoral conflicts.

The Supreme Court (Administrative Bench) examines and rules on all matters arising from the conduct of council elections. Appeals against rulings of the administrative judge are examined by the Plenary Assembly of the Supreme Court.

The Constitutional Council:

- ensures the regularity of presidential and legislative elections;

- adopts and proclaims the results of both presidential and legislative 
elections on the basis of reports submitted to it by the National Commission for the Final Counting of Votes;

- examines and rules on all matters arising from the conduct of presidential and legislative elections.

\section{The National Elections Observatory}

The NEO is the only authority, outside the supervisory commissions mentioned above, empowered by the legislature to supervise and control all electoral operations in Cameroon.

Section 2 of Law No 2000/016 of 19 December 2000 to set up a National Elections Observatory spells out its mission as follows:

NEO's mission shall be to contribute to the observance of the electoral law in order to ensure the regularity, impartiality, objectivity, transparency, and fairness of elections and to guarantee to voters and candidates the free exercise of their rights.

Section 6 of the same law lists the specific duties of the NEO - responsibility for supervising and monitoring all election management operation from the registration of voters to the publication of election results.

Thus Cameroon's election management landscape is occupied by several bodies of varying sizes and degrees of importance, whose functions are not always clearly defined and often tend to overlap and conflict. There have also been calls for a clarification of the roles of the various bodies in charge of election management and for the reduction of the role of the MINATD in the management of elections.

\section{ELECTION MANAGEMENT: PROBLEMS AND PROSPECTS}

The single most important challenge facing election managers in Cameroon is the building of public confidence in the electoral process to the extent that election results are readily accepted and cease to be the subject of such controversy that they threaten the stability of the country's democratic institutions at the end of each electoral process.

This major challenge calls for the introduction of several new measures including legislative reforms, the strengthening of EMBs, harmonisation of procedures, the curbing of impunity, the clarification and streamlining of functions, technological innovation and election funding, on which the next section turns the spotlight. 


\section{Legislative reform}

For public confidence in the electoral process to grow, election stakeholders must, firstly, accept the laws that govern elections as providing a level playing field for political competition for state power and thus be prepared to abide by them. Indeed, the need for reform of the legislation that governs elections in Cameroon has been acknowledged at the highest levels of the state apparatus and talks on the issue between the government and the other political stakeholders are expected to start soon.

Projected legislative reforms will focus primarily on updating existing electoral laws with a view to clarifying certain provisions which have been subject to conflicting interpretations and introducing new provisions to make room for the modernisation of the management of elections. Once updated and enriched the various electoral laws will be merged into an Electoral Code that will govern the conduct of future polls. In addition, a new law is awaited that will set up a body responsible for the conduct of all elections, thereby assuming the election management duties hitherto variously performed by MINATD, the numerous joint commissions described above, and the NEO.

\section{Strengthening EMBS}

It is important that the EMBs that will be set up by the new Electoral Code earn public confidence through the personal qualities of the people nominated to manage them, the manner in which these personalities are chosen, and the efficiency with which they perform their election management duties. The extent to which EMBs can perform their duties without undue interference from government and other interest groups will be a determining factor in the confidence-building process.

Thus far, of the numerous bodies currently responsible for various election management tasks, only the NEO seems to enjoy some measure of public confidence thanks to the fact that its members are chosen from civil society and have no direct ties either with the government or with political parties or candidates.

NEO members are appointed after consultation with political parties and other civil society organisations and the NEO enjoys a certain measure of independence in terms of decision-making and the organisation of its work. But its role is confined to the supervision and control of elections, an assignment it may carry on well without unfortunately being able to rid the electoral process of certain imperfections arising from failure on the part of the others involved in it effectively to play their roles. 


\section{Harmonisation of procedures}

On the whole, there is a need also to develop and codify election management procedures in such a manner that little room is left for the improvisation that tends to undermine public confidence in the electoral process. For instance, there are no set procedures for the registration of voters and the updating of existing voters' rolls. Each divisional officer may prescribe whatever procedures he or she deems convenient to be used within the area under his or her jurisdiction. What is more serious is the lack of consistency in the use of any given procedures.

\section{Curbing impunity}

Another major problem that needs to be addressed urgently by Cameroon's election managers is impunity. Despite efforts made to educate various election stakeholders, some of them persist in wrongdoing that affects the credibility of the process. Certain stakeholders deliberately perpetrate fraudulent activities for personal or group gain. For instance, certain administrative officials create bottlenecks in the registration of voters in an effort to restrict the number of voters in areas believed to be opposition party strongholds. In so doing they think they are rendering a service to the party in power and hope to earn a career promotion in return. In addition, some political parties encourage their supporters to cast multiple votes. Such wrongdoing is encouraged because perpetrators are hardly ever prosecuted. Law enforcement measures thus need to be strengthened and more emphasis laid on punishing defaulters.

\section{Clarification and streamlining of functions}

In the course of introducing new legislation to govern the conduct of elections in the country attention will have to be paid to clarifying and streamlining the role of whatever election management body or bodies are set up. One question that has been raised is how appropriate it is to involve political parties in the direct management of elections. Experience has shown that in situations where democratic principles have not become part of a society's value system partisan allegiance is liable to mar the proper functioning of election management structures that include party representatives. Cameroon may thus need to review the usefulness of its numerous joint commissions which include political party representatives.

\section{Technological innovation}

Information technology (IT) contributes to more efficient election management but it imposes prohibitive costs on countries with limited resources. 
Cameroon has opted to adopt IT for election management tasks such as the establishment of electronic voters' rolls and the production of election results and statistics. Plans for the introduction of these new technologies are currently being finalised. But proper care must be taken to make the use of IT cost effective.

\section{Election funding}

Elections are generally costly to organise and often strain the already scarce resources of many developing countries. Thus adequate funding remains a problem that numerous low-income countries will be unable to solve for a long time. Yet both the citizens of those countries and members of the international community insist on having properly organised and adequately funded elections.

The solution to this problem may lie in the adoption of low-cost election management procedures and the rational management of scare resources. Cameroon today has to provide funding not only to MINATD, which, directly or indirectly, handles most of the election management tasks, but also to the NEO, which is responsible for supervision and monitoring. There could be considerable savings if the duplication of functions and field personnel were avoided through a more rational distribution of roles. This is one of the issues that needs to be addressed during talks on election reform.

\section{CONCLUSION}

Cameroon will soon need to take some crucial decisions as it attempts to reform the legislative and practical provisions for the management of elections in the country. One thing that remains clear is that it would be unwise for the country to try to import election management procedures simply because they have been found to be effective elsewhere. Adaptability to the specific political, economic, social and cultural context that prevails within the country should be a primary concern for Cameroon or any other country which, like it, is striving to improve the quality of election management.

The norms and standards examined earlier in this paper will continue to be the guiding principles for election management in African countries, but one must expect each country to adopt and adapt them to its specific context. Khabele Matlosa (2003) has stressed the need to domesticate election management norms and standards:

... current democracy discourses in both academic and policy-making circles have probed the utility of liberal democracy in the African context and there is an emerging consensus that Africa needs to 
transcend liberal democracy and embrace wholesomely social democracy blended with African cultural practices and traditions.

Matlosa no doubt implies here that democracy cannot simply be imported into a country as one would import a car. But whether or not social democracy is a truly viable option remains to be seen.

The reluctance on the part of certain governments to relinquish control over EMBs and to allow them to be completely independent and financially autonomous is a phenomenon that will not go away in the near future. State sovereignty is the constant concern of governments and the fear that runaway independent election commissions may eventually come to be controlled by powers hostile to the state is a genuine one. For that reason, EMBs will have to work to allay such fears by increasing their efficiency and accountability within the terms of specific constitutional provisions.

Finally, as the gap between rich and poor countries continues to widen, the latter will find it more and more difficult to single-handedly assemble the resources necessary for the organisation of credible elections at regular intervals. If the efforts these countries are prepared to make are not be thwarted by poverty and the hopes of their peoples dashed by the backsliding of their democratic processes, the rich countries must seriously consider setting up a democracy solidarity fund to assist well-meaning but less privileged countries to stride towards democracy.

\section{- REFERENCES}

Mozaffar, S. 2002. 'Patterns of Electoral Governance in Africa's Emerging Democracies'. International Political Science Review 23(1).

Matlosa, Khabele. 2003. 'Electoral Systems and Multiparty Democracy in Southern Africa'. Paper presented at the Conference on Elections, Democracy and Governance, Pretoria, South Africa, April.

SADC Parliamentary Forum. 2001. 'Norms and Standards for Elections in the SADC Region'. 